\title{
Szapor, Judith, Hungarian Women's Activism in the Wake of the First World War: From Rights to Revanche. London: Bloomsbury Academic, 2018. 207 pp. Illus.
}

\author{
Reviewed by Judit Acsády", Center for Social Sciences, MTA, Budapest
}

Judith Szapor's Hungarian Women's Activism in the Wake of the First World War: From Rights to Revanche is a new work in the field of the history of Hungarian women's political activities and social movements in the early twentieth century. The history of feminism having been long silenced in Hungary has recently attracted new interest both there and abroad. Similarly, conservative women's organizations during and after World War I have also became the focus of recent research projects. Scholars from different backgrounds and countries, including those of the ex-Soviet bloc, joined efforts and produced a number of important works, among them edited volumes by Alison Fell, Ingrid Sharp, and Matthew Stibbe. Judith Szapor, the author of the book under review likewise belongs to this international research network, which was initially started and led by Sharp and Stibbe. Hungarian Women's Activism is based on Szapor's newest research supported by Canadian research grants at her Department of History and Classical Studies of McGill University.

The book includes five chapters with further subsections and a concluding chapter that summarizes the assumptions and describes the implications and the long-lasting social and historical effects of the ideological constructs of the 1920s discussed in the book. The main threads of the work are the intertwining levels of political history and the histories of organizations and individuals. The construction of Szapor's argumentation is not necessarily always linear but sometimes circular, with certain themes recurring in the text. She builds her main arguments and evaluations mostly on primary archival sources, newspapers and journals of the time under study, ego documents such as diaries and memoires, and literary works like novels and short stories.

In the Introduction two key events are presented to unfold the arguments about women's participation in public life, illustrating the keywords of the volume's subtitle, 'from rights to revanche:' first, the Seventh Congress of the International Woman Suffrage Alliance (IWSA), an international non-governmental organization focused primarily on gender equality, held in Budapest in June 1913. Second, and in sharp contrast, Szapor discusses the ceremony of Admiral Horthy's triumphal entry into Budapest astride a white horse as the head of the National Army on November 16, 1919, subsequent to which he was invited to become Regent of the Kingdom

*acsady.judit@tk.mta.hu

(cc) Br

ULLS D-Serle
New articles in this journal are licensed under a Creative Commons Attribution 4.0 International License.

This journal is published by the University Library System of the University of Pittsburgh as part of its D-Scribe Digital Publishing Program and is cosponsored by the University of Pittsburgh Press 
Acsády, Judit. "Szapor, Judith, Hungarian Women's Activism in the Wake of the First World War: From Rights to Revanche. London: Bloomsbury Academic, 2018. 207 pp. Illus." Hungarian Cultural Studies. e-Journal of the American Hungarian Educators Association, Volume 11 (2018) DOI: 10.5195/ahea.2018.329

by Parliament. The Congress of IWSA held in Budapest was hosted and organized by the Association of Feminists of Hungary, or FE, a Hungarian feminist organization founded in Budapest in 1904 as an associate to the IWSA itself. In contrast to the Congress, the entry of Horthy into Budapest was a symbolic beginning of the right-wing conservative regime of the interwar period. Szapor also explores women's participation and gendered references in that November 16 ceremony, assisted by the National Alliance of Hungarian Women or MANSZ ['Magyar Asszonyok Nemzeti Szövetsége'], a nationalist and revisionist organization, founded in 1919 by the writer Cecile Tormay.

In Chapter 1 Szapor gives an overview of women's organizations of the period 19041922 in Hungary including progressive feminist, socialist and Christian conservative groups, their ideological backgrounds and political aims. These decades have been well explored by earlier literature in the field, to which Szapor does not refer systematically, although she does provide a rather rich collection of references in her Bibliography. As far as the origins of the Hungarian feminist movement are concerned, beyond the defense of interests of white-collar working women, as the author describes, from the mid-nineteenth century on the movement was also rooted in the struggles for women's education and participation in public life (see Rózsa Schwimmer, A magyar nömozgalom régi dokumentuma [The Old Documents of Hungarian Women's Movements]. Budapest. 1907: 3-6). The FE never really defined itself as 'liberal,' which is a retrospective categorization applied by the author, which might serve to orient the English reader, yet it might not reveal the integrative political values and ideas of this movement in Hungary. Due to the variety of cultural and ideological traditions represented by the membership of this organization, this particular political categorization of the Hungarian movement might need to be reconsidered, as, to cite Karen Offen 'It would not be appropriate to postulate a hegemonic model' for the development of the multitude of feminisms' (European Feminisms 1700-1950: A Political History. Stanford: UP, 2000, 23).

Chapter 2 discusses the foundation, activities, and political involvement of the Hungarian Women's Debating Club in Budapest in 1918 by the noblewoman and wife of Count Mihály Károly, Katinka Andrássy and the pacifist and female suffragist, Rózsa Schwimmer. The history of the informal Club, initiated by aristocrats, but including women of other social classes, is reconstructed by Szapor on the base of Andrássy's personal diaries and Schwimmer's archive. Szapor elaborates exquisitely the motives of family histories and the biographies of individual women, concerning how they came to work together in this historical instance on different issues including women's suffrage. However, one might quibble with the author's judgment that Hungarian women of the aristocracy and noble classes were 'previously apolitical' (54). One might recall the several aristocrats from the eighteenth century on who were involved in political efforts, e.g. Teréz Brunszvik, Emília Kánya, Hermin Beniczky, Mrs. Pál Veres, Antonia, B. Szőgyény, Janka Zirzen, Kata Piroska Boldizsár, variously as founders of institutions, and associations, journal editors, leaders of schools and establishers of great collections.

Chapter 3 explores a turbulent phase of Hungarian history after the World War I, which included two revolutions. The events of both the 'aster revolution' with the formation of the National Council and the Károlyi government and the taking of the power by the communists in the Republic of Councils are followed step by step from a gender perspective. Women's participation in the work of the Central Revolutionary Council of Workers and in the work of different committees is precisely described. The author reveals the dynamics and the dilemmas 
Acsády, Judit. "Szapor, Judith, Hungarian Women's Activism in the Wake of the First World War: From Rights to Revanche. London: Bloomsbury Academic, 2018. 207 pp. Illus." Hungarian Cultural Studies. e-Journal of the American Hungarian Educators Association, Volume 11 (2018) DOI: 10.5195/ahea.2018.329

of feminist activists' involvement in formal politics, of choosing different paths as candidates joining political parties before the elections when finally women could vote and could be elected (64-65). The exquisite accounts of the battle for suffrage in this period, the steps of gaining and losing political rights for women in Hungary and the dynamics of women's participation at multiple levels in the two revolutions with changing motives and ideological settings are among the best merits of the work.

Chapter 4 and Chapter 5 discusses the period after the triumph of the counter revolutionary forces, led by Admiral Horthy in November 1919. Hungarian Women's Activism develops the argument that the rightist nationalist women's organization MANSZ reached a leading position after the new regime change, and the role of the conservative political actors including women's organizations came to the foreground. MANSZ not only supported the Horthy regime but with its publications and activities had also a key role in formulating government policies with special attention to the interlinking of the revanchist nationalistic politics with conservative gender ideology. As Szapor (4) had already pointed out in her Introduction [under the Horthy regime] the restoration (in contemporary parlance 'revision') of prewar borders went hand in hand with the restoration of social and gender order- at the expense of the liberal values and emancipation, political democracy and equal citizenship'. Szapor also discusses the political and personal level in relation to significant individual actors and their involvements in the revanchist politics, namely the authors, Cecile Tormay and Emma Ritoók. On the base of the personal diaries, memoires and literary works of art of these two well-known figures, she reconstructs the details of their ideological settings and their anti-Semitism, that suited the regime's rhetoric. Emma Ritoók had earlier belonged to a progressive group of thinkers, called the Sunday Circle, along with the politically leftist writer Anna Lesznai, whose works are contrasted with those of Ritoók, who left the circle to follow a politically conservative path.

In Chapter 6 of Hungarian Women's Activism the new phase of the ambiguous history of suffrage in Hungary is explored. 'In the January 1920 elections all men and women over the age twenty-four -with literacy requirement for women only - were required to vote, making this election a first for women and the most inclusive for men. This chapter also discusses the electoral campaigns of different parties and the end results. The author calls attention to a fairly important detail: the extremely high number of invalid votes that can be interpreted as protest votes, due to the fact that The Social Democratic party instructed their party members to 'cast invalid ballots'. In this monumental election the Roman Catholic social activist for human rights and Christian Democratic candidate Margit Slachta became the first woman in parliament in Hungary who won a seat. (It might be added that Slachta and her sisters aided Jews during the war, and one of her sisters was executed by the Arrow Cross, while she herself narrowly escaped execution. In 1984, a decade after her death, Slachta was recognized as Righteous Among the Nations in Yad Vashem.) While during this period the activism of progressive feminists became reduced, the conservative woman's group MANSZ developed an increasingly hostile criticism against them as a part of their rhetoric for the defense of the traditionalist gender values. The chapter concludes with the overview of the despair of feminist activism, which had until the end of World War I involved women all over the country through its widespread network and associates. The chapter finally describes the further erosion of civil rights, the contradictory limitations on suffrage by 1922 . 
In the Conclusion Szapor (152) summarizes that 'Despite the undeniable, significant extension of the vote, the history of electoral rights in Hungary serves as a cautionary tale: citizenship cannot be reduced to and grasped solely in terms of electoral legislation.' She also discusses the long-term impact of Tormay's literary works and the ideological constructs of the 1920's. Having been forgotten and forbidden after World War II for forty years during state socialism, Tormay's works were republished after the transition in 1990, and as the author claims they reemerged to have an impact on the ideological formulations of Hungarian society. The Conclusion also claims that in spite of all the activities by women and women's organizations' important roles 'gender policies and women's roles in public and private life were defined and set from above, without the involvement of the women whose choices these policies were meant to regulate' (155). Hungarian society having the legacies of two authoritarian regimes in the twentieth century after one another: during the interwar period and after 1948 until the transition, has the difficulty with the 'exception of short periods' of not having 'any experience of a working democracy’ (Szapor: 155).

Hungarian Women's Activism in the Wake of the First World War gives a perceptive historical overview of the roles of individual women and women's organizations in the formulation of the policies of the post-World War I years in Hungary. With a focus on gender relations of political events of the period the book explores the ways in which feminists, belonging to the FE, forwarded the case of women's social emancipation and the ways in which the right-wing, conservative, nationalistic women's groups and individual women authors contributed to the formulation and legitimation of the ideology of the Horthy regime in Hungary in the 1920s and how the conservative MANSZ participated in and took part in the restoration of social and gender order. The immense work devoted to the book contributes to the previous findings by revealing further details of the intersections of political activism and private lives and casts new illuminations on events by framing women's history of the 1920s into the long lasting political and ideological consequences. 